\title{
MOSAIC IN Senna occidentalis IN SOUTHERN BRAZIL INDUCED BY A NEW STRAIN OF Soybean mosaic virus
}

\author{
ÁLVARO M. R. ALMEIDA ${ }^{1}$, JUNICHI SAKAI ${ }^{2}$, ELIEZER R. SOUTO ${ }^{3}$, ELLIOT W. KITAJIMA $^{4}$, \\ TATIANA S. FUKUJI ${ }^{5} \&$ KAORU HANADA ${ }^{2}$
}

${ }^{1}$ Embrapa Soja, Cx. Postal 231, 86001-970, Londrina, PR, Brazil, almeida@ cnpso.embrapa.br; ${ }^{2}$ Laboratory Mol.

Pl. Pathol., Kyushu National Agricultural Experimental Station, 2421 Suya, Kikuchi, Kumamoto, 861-1192, Japan;

${ }^{3}$ Universidade Estadual de Maringá, CCA - DAG, Av. Colombo, 5790, 87020-900, Maringá, PR;

${ }^{4}$ Departamento de Fitopatologia, ESALQ, Cx. Postal 9, 13418-900, Piracicaba, SP; ${ }^{5}$ Universidade

Estadual de Londrina, Departamento de Química, Cx. Postal 6001, 86050-970, Londrina, PR

(Acepted for publication on 17/12/2001)

Corresponding author: Álvaro M. R. Almeida

ALMEIDA, A.M.R., SAKAI, J., SOUTO, E.R., KITAJIMA, E.W., FUKUJI, T.S. \& HANADA, K. Mosaic in Senna occidentalis in Southern Brazil induced by a new strain of Soybean mosaic virus. Fitopatologia Brasileira 27:151-156. 2002.

\section{ABSTRACT}

Plants of Senna occidentalis (sin. Cassia occidentalis) with mosaic symptoms were collected near a soybean (Glycine max) field where some plants exhibited symptoms of mosaic and blistering. A preliminary examination of leaf tissue from diseased $S$. occidentalis by electron microscopy revealed the presence of pinwheel inclusions as well as long flexuous particles, indicating the presence of a potyvirus. Host range, serology, and amino acid sequence from this potyvirus were similar to those from other Brazilian isolates of Soybean mosaic virus (SMV). The 3'- terminal region of the genomic RNA was cloned and a cDNA sequence of $1.9 \mathrm{~kb}$ upstream of the poly (A) tract was determined. The sequence contains a single open reading frame and a $3^{\prime}$ - non-translated region (NTR) of $259 \mathrm{bp}$. The nucleotide sequence of the CP gene of SMV-Soc was $98 \%$ identical to that of Brazilian isolates SMV-B, SMV-L, and SMV-FT10. The percentage of nucleotide identity of their 3'-NTR's was 91, 98, and 99\% in relation to SMV-L, SMV-B, and SMV-FT10, respectively. In contrast to other Brazilian SMV isolates studied, SMV-Soc was able to infect sunflower (Helianthus annuus). Based on these results, the $S$. occidentalis isolate was identified as a new strain of SMV belonging to the SMV strain, group G5 and was named SMV-Soc. This is the first report of naturaly occurring SMV infecting plants of $S$. occidentalis in Brazil, adding this weed as a new source of SMV in the field.

Additional keywords: SMV, potyvirus, taxonomy.

\section{RESUMO}

\section{Mosaico em Senna occidentalis no Sul Brasil causado por uma estirpe do Soybean mosaic virus}

Plantas de Senna occidentalis (sin. Cassia occidentalis) com sintomas de mosaico foram coletadas próximas a plantas de soja (Glycine max), com sintomas de mosaico e formação de bolhas no limbo foliar. Amostras dessas plantas foram analisadas por microscopia eletrônica constatando-se a ocorrência de inclusões citoplasmáticas tipo catavento e partículas flexuosas e alongadas, indicando a presença de potyvirus. Estudos adicionais com hospedeiras diferenciais, sorologia e sequência de aminoácidos demonstraram que o vírus era similar ao vírus do mosaico comum da soja (Soybean mosaic virus, SMV). Este isolado, designado SMVSoc, foi capaz de infetar plantas de girassol (Helianthus annuus), normalmente não infetada pelo SMV. Um fragmento de aproximadamente 1.9 kb, correspondendo à porção 3’ do RNA viral (parte da região codificadora da proteína Nib, toda a CP e a 3'NTR) foi amplificado via PCR, clonado e sequenciado. A sequência do gene da capa protéica do SMV-Soc apresentou 98\% de identidade com isolados brasileiros do SMV (SMV-B, SMV-L e SMV-FT10). A identidade de nucleotídeos da região 3'-NTR foi de 91, 98 e $99 \%$ em relação aos isolados SMVL, SMV-B E SMV-FT10, respectivamente. De acordo com esses resultados o isolado obtido de $S$. occidentalis foi considerado uma estirpe do SMV, grupo G5 e denominado SMV-Soc. Este é o primeiro relato da ocorrência natural do SMV em plantas dessa espécie e indica seu potencial como hospedeira natural deste vírus, no Brasil.

\section{INTRODUCTION}

Soybean [Glycine $\max (\mathrm{L}$.) Mer.] became one of the most important crops in Brazil after the expansion of its cultivation in the 70's. The yield average in 1999/2000 was 2.7 ton/ha (CONAB, 2000) although the potential yield is estimated to be higher than 3 ton/ha. Unfavourable weather conditions and diseases have been responsible for the yield reduction. Soybean mosaic virus (SMV) family Potyviridae, genus Potyvirus is seed borne (Kendrick \& Gardner, 1924) transmitted by several species of aphids (Abney et al., 1976) and widespread in Brazil causing lower yields or discarded mottled seeds as reported worldwide (Ross, 1968). Infected seeds are considered the main source of primary inoculum, with aphids contributing to the spread of secondary virus in the field (Hill et al., 1987).

Several strains of SMV (G1 through G7) have been identified on the basis of their pathogenicity to differential 
soybean lines (Cho \& Goodman, 1979) and the transmission by aphid species (Abney et al., 1976). SMV strains have also been divided into three serological groups by means of one-dimensional trypsin peptide maps immunoblotted with 12 monoclonal antibodies (Hill et al., 1987). Particles are flexous rods ca. $15 \mathrm{~nm}$ x $750 \mathrm{~nm}$, each containing a single type of capsid protein and a single RNA molecule. The capsid protein has a molecular weight ranging from 29.8 to $34 \mathrm{kDa}$ (Eggenberger et al., 1989). The SMV genome is a monopartite, single-stranded positive-sense RNA consisting of approximately $10 \mathrm{~Kb}$ with a $3^{\prime}$ poly (A) tail and a 5'terminal genome linked protein (VPG) (Hari, 1981).

Control of SMV around the world has been done through genetic resistance, confered by an allelic series of dominant genes (Kiihl and Hartwig, 1979). However, there are reports of new strains that have overcome this type of resistance (Almeida et al., 1995). Therefore, frequent field surveillance is required to detect such strains before they become a problem to farmers.

Recently, plants of Senna occidentalis (L.) Link (previously known as Cassia occidentalis L.) growing nearby soybean fields, where SMV-affected plants were present, were collected in Londrina, Southern Brazil. Using electron microscopy, samples were observed to contain flexous particles and cylindrical inclusions indicating infection by a potyvirus. This work demonstrate that the characteristics of this potyvirus isolated from $S$. occidentalis show it to be a unique strain of SMV.

\section{MATERIAL AND METHODS}

\section{Viral isolates and host range}

The leaves of $S$. occidentalis with mosaic symptoms collected at Londrina were used for mechanical inoculation and biological assays. This virus isolate will be referred to as SMV-Soc. One gram of tissue was ground in $10 \mathrm{ml}$ of $0.01 \mathrm{M}$ sodium phosphate buffer $\mathrm{pH} 7$. The extract was rubbed onto leaves of several botanical species, previously dusted with fine charcoal. Inoculated leaves were later washed with water and the plants were kept in a greenhouse. Symptoms were evaluated at ten and 20 days after inoculation. The presence of the virus in asymptomatic plants was verified by back inoculation to $S$. occidentalis and soybean cv. Santa Rosa, the same species in which the virus was propagated. Other isolates of SMV used in this work SMV-L, SMV-FT10, SMV-Y and SMV-B were collected in soybean fields in Brazil and are kept at the National Soybean Research Center at Londrina. Differential soybean genotypes were used according to Cho \& Goodman (1979) for strain identification.

\section{Virus purification}

Symptomatic soybean leaves cv. Santa Rosa were harvested approximately 30 days after inoculation. The virus was purified according to Lima et al. (1997). Virus concentration was determined using an extinction coefficient of 2.8 (Stace-Smith \& Tremaine, 1970). The molecular weight of the capsid protein was estimated by sodium dodecyl sulfate (SDS) - polyacrilamide gel electrophoresis on a 3.5\% stacking gel and a $12 \%$ resolving gel. After electrophoresis for $2 \mathrm{~h}$ at $120 \mathrm{~V}$ at room temperature, proteins were stained with coomassie brilliant blue. Protein molecular weight was estimated by comparing their relative mobility with molecular weight standards (Gibco BRL).

\section{Serological analysis}

Antiserum was produced by mixing equal volumes of purified viral solution (containing approximately $450 \mathrm{ug}$ / $\mathrm{ml}$ of virus) with Freund's complete adjuvant (Difco) and intramuscular injection of rabbit. Second, third, and fourth injections were prepared with incomplete adjuvant, containing the same amount of virus and made at 10-day intervals. Bleedings began two weeks after the first injection and continued for six weeks. Double diffusion tests were performed according to Purcifull \& Bachelor (1977).

Immunoglobulin was prepared according to Clark \& Bar-Joseph (1984) using ammonnium sulphate precipitation.

Indirect ELISA was conducted according to Koenig (1981) using antiserum against PVYo (Dr. André Dusi, CNPH, Embrapa, Brasília, DF) and SMV (Dr. J.A.A. Lima, UFC, Fortaleza, CE). Microtiter plates were covered with antigen (infected and healthy tissue) previously ground in coating buffer at 1:20 dilution, and incubated for $2 \mathrm{~h}$ at 37 ${ }^{\circ} \mathrm{C}$. Imunoglobulin was used at $0.8 \mathrm{ug} / \mathrm{ml}$. Goat anti-rabbit IgG-alkaline phosphatase conjugate (A-8025, Sigma Immuno-Chemicals, USA) was used at 1:8,000 dilution and incubated for $2 \mathrm{~h}$ at $37^{\circ} \mathrm{C}$. Twenty minutes after adding the substrate (p-nitrophenil phosphate), absorbance $\left(\mathrm{A}_{405 \mathrm{~nm}}\right)$ was read on a microplate reader (Mod. 3550 UV, BioRad, USA). A reaction was considered positive if the reading exceeded three times the mean value for healthy tissue.

\section{Electron microscopy}

Small pieces of leaves from plants infected by SMVSoc were fixed in a modified Karnovsky fixative $(2.5 \%$ glutaldehyde, $2.5 \%$ paraformaldehyde in $0.05 \mathrm{M}$ cacodylate buffer, $\mathrm{pH} 7.2$ ), post-fixed with $1 \% \mathrm{O}_{\mathrm{s}} \mathrm{O}_{4}$, dehydrated in acetone and embedded in Spurr's low viscosity resin. Sections were stained with uranyl acetate and Reynold's led citrate and examined in a Zeiss EM 900 transmission electron microscope. Viral particles were also observed in leaf dip preparations negatively stained with uranyl acetate (Kitajima \& Nome, 1999).

\section{Total nucleic acid extraction and reverse transcription}

Total RNA was extracted from $100 \mathrm{mg}$ of fresh leaf tissue ground in liquid nitrogen according to the RNeasy ${ }^{\circledR}$ Plant Kit protocol (Qiagen ${ }^{\circledR}$, Chatsworth, CA). The cDNA was synthesized using reverse transcriptase (Gibco BRL) and buffers according to the manufacturer in a final volume of $30 \mu \mathrm{l}$. From the total RNA extraction solution, $10 \mathrm{ml}$ were taken and mixed with $2 \mu$ of P89 primer $(10 \mu \mathrm{M})$ 
(Chavi et al., 1997), incubated at $70{ }^{\circ} \mathrm{C}$ for $10 \mathrm{~min}$ and quenched on ice for at least $1 \mathrm{~min}$. After that, other reaction components were added in the following order: $3 \mu \mathrm{l}$ of $10 \mathrm{X}$ PCR buffer (200 mM Tris-HCl, pH 8.4), $500 \mathrm{mM} \mathrm{KCl,} 25$ $\mathrm{mM} \mathrm{MgCl} 2(2 \mu \mathrm{l}), 10 \mathrm{mM}$ dNTPmix $(1 \mathrm{ml}), 0.1 \mathrm{M}$ dithiothreitol $(2 \mu \mathrm{l})$ and $1 \mathrm{ml}(20 \mathrm{U})$ of M-MLV reverse transcriptase (Gibco BRL), and DEPC treated water to give a reaction volume of $30 \mu \mathrm{l}$. The tubes were incubated for 1 $\mathrm{h}$ at $37{ }^{\circ} \mathrm{C}$ on a Perkin Elmer thermocycler model 9600 followed by $10 \mathrm{~min}$ of heating at $65{ }^{\circ} \mathrm{C}$ to denature the enzyme.

\section{Amplification by PCR}

Primer P89 and degenerate primer Pot2 (Colinet et al., 1998) were used for PCR. This primer set was designed to amplify part of the nuclear inclusion b coding region, the entire coding region and the $3^{\prime}$ - non-translated region of potyvirus. PCR reactions were performed in a $40 \mu \mathrm{l}$ volume, containing $10 \mathrm{mM}$ each of dATP, dCTP, dGTP, and dTTP, 2 $\mu 1$ of each primer $(10 \mu \mathrm{M}), 2.5 \mathrm{U}$ of Taq DNA Polymerase (Gibco BRL), $4 \mu$ of $10 \mathrm{X}$ PCR buffer, $25 \mathrm{mM} \mathrm{MgCl}_{2}$, and 4 $\mu l$ of the first strand synthesis product. Thirty-seven reaction cycles were performed as follows: template denaturation at $94{ }^{\circ} \mathrm{C}$ for $30 \mathrm{~s}$, primer annealing at $40{ }^{\circ} \mathrm{C}$ (cycles 1-5) and $50{ }^{\circ} \mathrm{C}$ (cycles 6-37) for $1 \mathrm{~min}$, and elongation at $72{ }^{\circ} \mathrm{C}$ for 2 min. A final 15 min elongation step at $72{ }^{\circ} \mathrm{C}$ was performed at the end of the 37 cycles.

\section{Nucleotide sequencing, sequence comparison and phylogenetic analysis}

Both strands were sequenced by the dideoxy chaintermination method, using a 373A DNA sequencer (ABI, USA). Nucleotide sequences were analyzed using the GCG software package, and compared with sequences deposited at the GenBank and EMBL databases. Multiple sequence alignments and dendrograms were produced using CLUSTAL W (Thompson et al., 1994) and the Phylogeny Inference Package (PHYLIP) developed and distributed by J. Felsenstein (Department of Genetics, University of Washington, Seattle, WA).

\section{RESULTS AND DISCUSSION}

\section{Host range and reactions}

Seven out of the 22 plant species tested, mostly legumes, were infected by both SMV and SMV-Soc (Table 1), indicating a narrow host range. Comparative studies showed that SMV-Soc and other SMV isolates have similar host ranges, the only differences being the ability of SMVSoc to infect sunflower (Helianthus annuus L.) and to cause systemic necrosis in Nicotiana benthamiana Domin (Table 1). Symptoms on infected plants ranged from typical mosaic to necrotic local lesions and leaf malformation. Based on the set of differential soybean genotypes used to differentiate SMV strains (Cho \& Goodman, 1979), SMV-Soc was included in strain group G5 (Table 2).

\section{Purification}

The method used for purification of SMV-Soc yielded an average of $6 \mathrm{mg}$ of virus $/ 100 \mathrm{~g}$ soybean leaf tissue. SDSPAGE analysis of purified preparations indicated the presence of a single protein with a relative molecular weight of $30.54 \pm 0.32 \mathrm{kDa}$ (mean of four determinations \pm standard deviation). No partially proteolyzed products were observed. The average relative mass for the capsid protein of SMVSoc, as determined in three SDS-PAGE experiments, is consistent with values reported for SMV and potyviruses in general (Hill \& Benner, 1980; Shukla et al., 1994).

\section{Serology}

Antiserum prepared to SMV-Soc reacted specifically to the purified virus as well as to SMV isolates in double gel diffusion and microprecipitin tests (titers of 4 and 512, respectively) (data not shown). In indirect ELISA it was not necessary to absorb the gamma globulin with healthy leaf extracts to reduce the background. This highly specific SMVSoc antiserum strongly cross reacted with all SMV isolates tested, indicating a close serological relationship between SMV-Soc and other SMV strains used (Figure 1). The highest ELISA values were observed in homologous reactions. Serological data did not help to discriminate the isolates, since potyvirus isolates can be serologically closely related. As mentioned by Shukla \& Ward (1988) and Shukla et al. (1994), cross reactions among potyviruses may cause misinterpretations. Despite the occurrence of lower ELISA values for heterologous reactions, they were still considered strong, suggesting that the existence of cross-reaction may be due to the occurrence of similar epitopes (Figure 1). This could be correlated to coat protein amino acid homologies higher than $80 \%$ as seen for viruses serologically related to SMV (Table 3).

SMV-Soc and other SMV strains reacted well in reciprocal PTA (plate traped antigen)-ELISA but could not be discriminated in this type of test.

\section{Electron microscopy}

Cytopathology of the tissues infected by SMV-Soc, characterized by the presence of cylindrical inclusions in the cytoplasm, provided the first evidence that the virus found in $S$. occidentalis was a potyvirus. Confirming preliminary observations, flexous particles $c a .15 \mathrm{~nm}$ x 750 $\mathrm{nm}$ were consistently detected in leaf dip preparations from infected plants (Figure 2A). In the sections from experimentally infected plants leaf tissues, cylindrical inclusions of type 3 in Edwardson's classification (Edwardson, 1974) were always present in the cytoplasm of infected cells consistent with the type of cylindrical inclusions induced by the SMV (Figures 2B, C). Fibrous, elongated particles frequently seen in the cytoplam (Figure $2 \mathrm{C}$ ) were immunogoldlabeled with anti-SMV-Soc antibody, confirming that they represent SMV-Soc virions in situ (Figure 2D).

\section{Sequence analysis}

Studies involving molecular techniques such as 
A.M.R. Almeida et al.

TABLE 1 - List of plant species used for host range studies with a potyvirus isolated from Senna occidentalis

\begin{tabular}{|c|c|c|c|c|c|c|}
\hline \multirow{2}{*}{ Family } & \multirow{2}{*}{ Species and cultivar } & \multicolumn{5}{|c|}{ Reaction of each isolate $^{1}$} \\
\hline & & SMV - Soc. & SMV - L & FT-10 & SMV-Y & SMV-B \\
\hline Amaranthaceae & Amaranthus sp. & - & - & - & - & - \\
\hline \multirow[t]{2}{*}{ Chenopodiaceae } & Chenopodium amaranticolor Coste \& Reyn. & NLL & NLL & NLL & NLL & NLL \\
\hline & Chenopodium quinoa Willd & - & - & - & - & - \\
\hline \multirow[t]{2}{*}{ Compositae } & Helianthus annuus L. & $\mathrm{M}, \mathrm{NL}$ & - & - & - & - \\
\hline & Emília sonchifolia (L.) DC & - & - & - & - & - \\
\hline \multirow[t]{16}{*}{ Leguminosae } & Glycine $\max (L)$. Mer. & & & & & \\
\hline & 'Santa Rosa' & M & M & M & M & M \\
\hline & 'Davis' & - & - & M & - & - \\
\hline & 'FT-10' & - & - & M & - & - \\
\hline & Phaseolus vulgaris L. & & & & & \\
\hline & 'Rosinha' & - & - & - & - & - \\
\hline & 'Carioca' & - & - & - & - & - \\
\hline & 'Tibagi' & $\mathrm{D}$ & - & - & - & - \\
\hline & Lupinus albus L. & - & - & - & - & - \\
\hline & Crotalaria pallida Ait. & - & - & - & - & - \\
\hline & C. mucronata Desv. & M & M & M & M & M \\
\hline & C. spectabilis Roth. & - & - & - & - & - \\
\hline & Arachis hypogeae L. & - & - & - & - & - \\
\hline & Vigna unguiculata L. Walp. 'Pitiúba' & - & - & - & - & - \\
\hline & Pisum sativum $\mathrm{L}$. & M & - & - & - & - \\
\hline & Senna occidentalis ( L.) Link & M & M & M & M & M \\
\hline \multirow[t]{4}{*}{ Solanaceae } & Lycopersicon esculentum Mill. & - & - & - & - & - \\
\hline & Nicotiana tabacum L. 'Sansun NN' & - & - & - & - & - \\
\hline & N. glutinosa $\mathrm{L}$. & M & - & - & - & - \\
\hline & N. benthamiana & SN & M & M & M & M \\
\hline Amaranthaceae & Gomphrena globosa $\mathrm{L}$. & - & - & - & - & - \\
\hline Cucurbitaceae & Cucurbita pepo L. 'Caserta' & - & - & - & - & - \\
\hline Compositae & Bidens pilosa $\mathrm{L}$ & - & - & - & - & - \\
\hline
\end{tabular}

${ }^{1} \mathrm{M}=$ mosaic; $\mathrm{NLL}=$ necrotic local lesion; $\mathrm{SN}=$ systemic necrosis; $\mathrm{MM}=$ mild mosaic; $\mathrm{D}=\mathrm{dwarfing} ;$ - = no symptom

nucleotide sequences of viral RNA are useful for strain and virus differentiation, as already mentioned by several authors (D’Aquino et al., 1995; Seifers et al., 2000). Sequences of the capsid protein gene from the isolates used in this study were compared among themselves and also with other sequences available in the GenBank.

Three recombinant clones with $1.9 \mathrm{~Kb}$ were obtained for SMV-Soc and the other SMV isolates. Their 3'-terminal 1,227 nucleotides were sequenced, encompassing the $\mathrm{C}$ terminal region of the $\mathrm{NIb}$, the entire $\mathrm{CP}$, and the $3^{\prime}$-nontranslated region (3'NTR). The $3^{\prime}$-NTR of SMV-Soc was $259 \mathrm{bp}$ long and shares percentage homology of 91 and $99 \%$ with SMV isolates from Brazil, and 89 and $92 \%$ with American SMV strains G2 and G7, respectively (Table 3). The CP region of SMV-Soc was 795 nucleotide long encoding for a protein of 265 amino acid residues that starts with serine. The amino acid sequence shares homology percentages of $98 \%$ with Brazilian isolates of SMV and American strains SMV-G2 through SMV-G7 (Table 3). Brazilian isolates appear not to be closely related genetically to American strains of SMV (G2 and G7).

The amino acid sequence of the CP region of SMVSoc and other Brazilian SMV isolates, as well as American isolates of SMV-G1 through G7, are 97 to $98 \%$ identical, supporting the identification of SMV-Soc as a strain of SMV.

TABLE 2 - Strain classification of Soybean mosaic virus (SMV) isolates based on the reaction* on soybean (Glycine max) differential cultivars according to Cho \& Goodman (1979)

\begin{tabular}{|c|c|c|c|c|c|}
\hline \multirow{2}{*}{ Cultivar } & \multirow{2}{*}{ SMV-Soc } & \multicolumn{4}{|c|}{ SMV isolates } \\
\hline & & SMV-L & SMV FT-10 & SMV-Y & SMV-B \\
\hline Bufalo & - & - & - & - & - \\
\hline Davis & M & - & M & - & M \\
\hline Hood & - & - & SN & - & M \\
\hline Marshall & - & - & $\mathrm{VN}$ & - & - \\
\hline Ogden & - & - & - & - & - \\
\hline PI 96983 & - & - & - & - & SN \\
\hline PI 483084 & - & - & SN & - & - \\
\hline Santa Rosa & M & M & M & M & M,B \\
\hline Strain & G5 & G1 & G4 & G1 & G6 \\
\hline
\end{tabular}




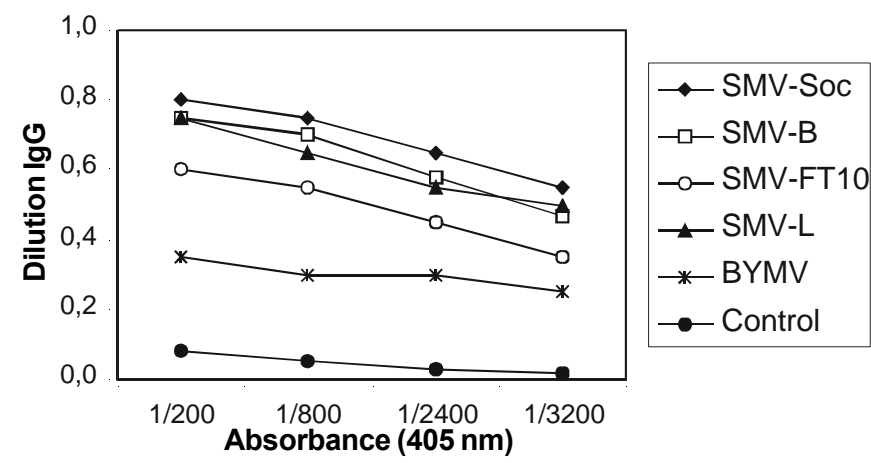

FIG. 1 - Serological relationship among strains of Soybean mosaic virus (SMV-B, SMV-FT10 and SMV-L) and other potyvirus (Bean yellow mosaic virus) using IgG prepared from antiserum against SMV isolated from Senna occidentalis (SMV-Soc). The immunoglobulin was used at $1 \mu \mathrm{g} / \mathrm{ml}$. The O.D. ${ }_{405 \mathrm{~nm}}$ values recorded $20 \mathrm{~min}$ after addition of substrate.

The homology percentage of the 3'- NTR of SMV-Soc with Brazilian SMV isolates ranges from 91 to $99 \%$ and, from 89 to $92 \%$ with American isolates (strains G2 and G7, respectively).

The length and sequence of the 3 ' non-translated tail is highly conserved among strains of a potyvirus (83\% to 99\%) (Frenkel et al., 1989). One could speculate that SMVG5, G3 and G6, represent an intermediate group of SMV strains more closely related to the Brazilian isolates of SMV than to SMV-G1, G2 or G7. This could be explained by the effect of continuous selection pressure for these isolates over the years, causing adaptation of Brazilian soybean genotypes.

Results described in this paper show that the virus infecting Sennna occidentalis is a new strain of SMV, classified in the G5 group (Cho \& Goodman, 1979). This strain is able to infect sunflower, a species not involved in the SMV-soybean pathosystem.

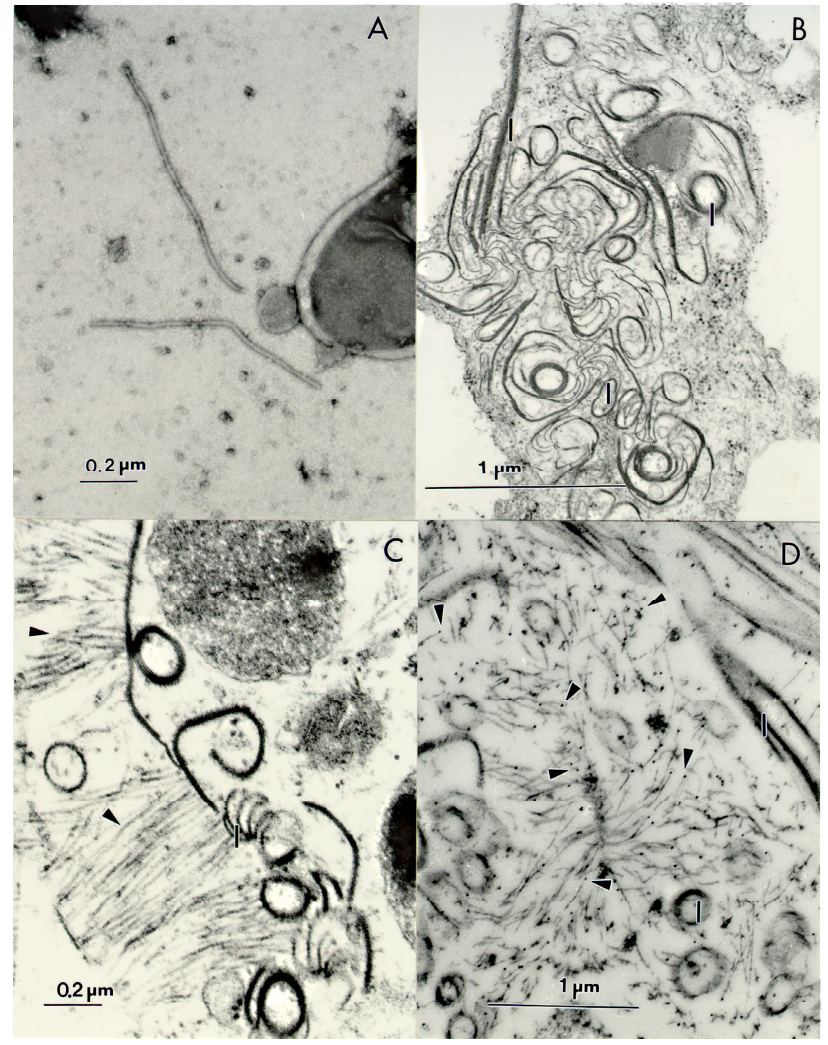

FIG. 2 - Transmission electron micrographs: A. Leaf dip preparation from Senna occidentalis naturally infected by Soybean mosaic virus (SMV-Soc) showing flexous particles measuring ca. 15 x 750 nm. B-D. Thin sections of leaf tissues from plants experimentally infected by SMV-Soc. B. Senna occidentalis; C. Soybean (Glycine max). Note the cylindrical inclusions (I) and flexuous particles (arrow heads) in the cytoplasm, typical of potyviruses. The latter became immunogoldlabeled when treated with anti-SMV-Soc serum (D) (see some gold particles at arrow heads).

TABLE 3 - Percentage of identities of 3' NTR nucleotides and coat protein amino acid sequence of Senna occidentalis isolate (SMV-Soc) compared to Brazilian isolates of Soybean mosaic virus (SMV-B, SMV-L and SMV-FT) and SMV serologically related potyviruses $(*)$

\begin{tabular}{|c|c|c|c|c|c|c|c|c|c|c|c|c|c|c|}
\hline$\%$ & SMV-G1 & SMV-G2 & SMV-G3 & SMV-G5 & SMV-G6 & SMV-G7 & SMV-FT & SMV-L & SMV-Soc & SMV-B & WMV-2 & BCMV & CYVV & BYMV \\
\hline SMV-G2 & 99 & & - & - & - & 92 & 90 & 89 & 89 & 89 & 80 & 65 & 16 & 29 \\
\hline SMV-G3 & 98 & 99 & & - & - & - & - & - & - & - & - & - & - & - \\
\hline SMV-G5 & 98 & 98 & 99 & & - & - & - & - & - & - & - & - & - & - \\
\hline SMV-G6 & 98 & 99 & 100 & 99 & & - & - & - & - & - & - & - & - & - \\
\hline SMV-G7 & 98 & 98 & 98 & 98 & 98 & & 90 & 92 & 92 & 93 & 82 & 64 & 40 & 31 \\
\hline SMV-FT10 & 97 & 97 & 98 & 98 & 98 & 97 & & 91 & 91 & 91 & 82 & 68 & 27 & 30 \\
\hline SMV-L & 97 & 98 & 98 & 98 & 98 & 97 & 96 & & 98 & 99 & 82 & 68 & 12 & 31 \\
\hline SMV-Soc & 98 & 98 & 98 & 98 & 98 & 98 & 98 & 98 & & 99 & 81 & 66 & 16 & 30 \\
\hline SMV- B & 98 & 98 & 98 & 97 & 98 & 98 & 97 & 98 & 98 & & 82 & 67 & 16 & 30 \\
\hline WMV- 2 & 87 & 87 & 87 & 87 & 87 & 87 & 86 & 86 & 86 & 87 & & 69 & 15 & 29 \\
\hline CYVV & 55 & 55 & 55 & 55 & 55 & 55 & 55 & 55 & 55 & 55 & 53 & 44 & & 72 \\
\hline BYMV & 59 & 59 & 59 & 59 & 59 & 59 & 58 & 59 & 59 & 58 & 58 & 50 & 72 & \\
\hline SuCMV & 57 & 58 & 58 & 58 & 58 & 58 & 56 & 57 & 56 & 57 & 59 & 56 & 57 & 60 \\
\hline
\end{tabular}

*SMV is closely related serologically to WMV-2 and distantly to BCMV, BYMV and CYVV (Purcifull \& Hiebert, 1979; Edwardson \& Christie, 1991). Sequence identities were calculated by making pairwise comparisons using the Clustal W program (1.81 version). GenBank accessions: Soybean mosaic virus (SMV): SMV-G1(AF200560), SMV-G2 (S42280), SMV-G3 (AF200563), SMV-G5 (AF200566), SMV-G6 (AF200569), SMV-G7 (AF241739), Watermelon mosaic virus-2: WMV-2 (D00535), Bean common mosaic virus: BCMV (U19287), Clover yellow vein virus: CYVV (AB011819), Bean yellow mosaic virus: BYMV (D00604), Sunflower chlorotic mottle virus: SuCMV (AF255677). Comparisons above the diagonal refer to the 3' NTR and comparisons below the diagonal refer to coat protein genes. ( - ) There is no sequencing data information for the 3' NTR of SMV-G1, G3, G5, G6 and for SuCMV in the GenBank. 
Senna occidentalis was also identified as a new source of SMV in the field.

In Brazil, at least 13 viruses have been described as infecting soybean, the most common being SMV. Moreover, at least three strains of SMV have been reported (Almeida et al., 1995). The occurrence of $S$. occidentalis with symptoms of mosaic nearby soybean plants with similar symptoms suggested that the same virus could be involved. Previous reports mentioned the biological and serological characterization of a potyvirus isolate obtained from $S$. occidentalis in the Northeast of Brazil, although the virus was considered as a possible strain of Cowpea aphid-borne mosaic virus another member of the family Potyviridade genus Potyvirus (Lima \& Gonçalves, 1988; Santos et al., 1991).

\section{ACKNOWLEDGMENTS}

The authors are grateful to the Japan International Research Center for Agricultural Science (JIRCAS) for financial support for this work. We thank L. C. Benato and $\mathrm{N}$. Valentin for their technical assistance with this project.

\section{LITERATURE CITED}

ABNEY, T.S., SILLINGS, J.O., RICHARDS, T.L. \& BROERSMA, D.B. Aphids and other insects as vectors of soybean mosaic virus. Journal of Economic Entomology 69:254-256. 1976.

ALMEIDA, A.M.R., ALMEIDA, L.A., KIIHL, R.A.S. \& DOMIT, L. Uma nova estirpe do virus do mosaico comum da soja identificada no Brasil. Brazilian Archives of Biology and Technology 38:1095-1100. 1995.

CHAVI, F., ROBERTSON, A.I. \& VERDUION, B.J.M. Survey and characterization of viruses in sweet potato from Zimbabwe. Plant Disease 81:1115-1122. 1997.

CHO, E.K. \& GOODMAN, R.M. Strains of soybean mosaic virus: classification based on virulence in resistant cultivars. Phytopathology 69:467-470, 1979.

CLARK, M.F. \& BAR-JOSEPH, M. Enzyme immunosorbent assay in plant virology. In: Maramorosh, K. \& Koprowsky, H. (Eds.) Methods in virology. New York, Academic Press, 1984. pp.5185.

COLINET, D., NGUYEN, M., KUMMERT, J., LEPOIVRE, P. \& XIA, F.Z. Differentiation among potyviruses infecting sweet potato based on genus-and virus-specific transcription polymerase chain reaction. Plant Disease 82:223-229. 1998.

CONAB. Ministério da Agricultura. Indicadores da Agropecuária. Ano IX. N. 9. Setembro, 2000.

D'AQUINO, L., DALMAY, T., BURGYÁN, J., RAGOZZINO, A. $\&$ SCALA, F. Host range and sequence analysis of an isolate of potato virus Y. Plant Disease 79:1046-1050. 1995.

EDWARDSON, J.R. Some properties of the potato virus Y-group. Florida Experimental Station Monograph Series No.4. 1974.

EGGENBERGER, A.L., STARK, D.M. \& BEACHY, R.N. The nucleotide sequence of a soybean mosaic virus coat proteincoding region and its expression in Escherichia coli, Agrobacterium tumefasciens and tobacco callus. Journal of General Virology 70:1853-1860. 1989.

FRENKEL, M.J., WARD, C.W. \& SHUKLA, D.D. The use of 3'non- transcoding nucleotide sequences in taxonomy of potyviruses: Application to watermelon mosaic virus 2 and soybean mosaic virus. Journal of General Virology 70: 2775-2783. 1989.

HARI, V. The RNA of tobacco tech virus: further characterizatiopn and detection of protein linked to RNA. Virology 112:391399. 1981.

HILL, J.H., BAILEY, T.B., BENNER, H.I., TACHIBANA, H. \& DURAND, D.P. Soybean mosaic virus: effects of primary diseases incidence on yield and seed quality. Plant Disease 71:237-239. 1987.

HILL, J.H. \& BENNER, H.I. Properties of soybean mosaic virus ribonucleic acid. Phytopathology 70:236-239. 1980.

KENDRICK, J.B. \& GARDNER, M.W. Soybean mosaic: seed transmission and effect on yield. Journal of Agricultural Research 27:91-98.1924.

KIIHL, R.A. de S. \& HARTWIG, G.E.E. Inheritance of reaction to soybean mosaic virus in soybeans. Crop Science 19:372-375. 1979.

KITAJIMA, E.W. \& NOME, C. F. Microscopia electrónica em virologia vegetal. In Docampo, D.M. \& Lenardón, S.L. (Eds.) Métodos para detectar patógenos sistémicos. Córdoba, IFFIVE/ INTA-JICA 1999. pp. 59-87.

KOENIG, R.Indirect ELISA methods for the broad specificity detection of plant viruses. Journal of Geneneral Virology 55:5362. 1981.

LIMA, J.A.A. \& GONÇALVES, M.F.B. Cassia occidentalis, potencial reservatório de potyvirus que infetam caupi. Fitopatologia brasileira 13:365-368. 1988.

LIMA, J.A.A., SILVEIRA, S.B., SOUZA, A.E.B.A.\& ALMEIDA, A.M.R. An efficient method for purification of soybean mosaic virus and production of a highly specific policlonal antiserum. Virus Review \& Research 2:57-67. 1997.

PURCIFULL, D.E. \& BACHELOR, D.L. Immunodiffusion tests with sodium dodecyl sulfate (SDS)-treated plant viruses and plant viral inclusions. Agricultural Experiment Stations, University of Florida, Bulletin 788. 1977.

ROSS, J.P. Effect of single and double infections of soybean mosaic virus and bean pod mottle viruses on soybean yield and seed characters. Plant Disease Reporter 52:344-348. 1968.

SANTOS, A.A., COSTA, C.L., KITAJIMA, E.W. \& MEYER, M.C. Um virus isolado de Casia occidentalis. Fitopatologia Brasileira 16:308. 1991 (Resumo).

SEIFERS, D.L., SALOMON, R., MARIE-JEANNE, V., ALLIOT, B., SIGNORET, P., HABER, S., LOBODA, A., ENS, W. \& STANDING, K.G. Characterization of a novel potyvirus isolated from maize in Israel. Phytopathology 90:505-513. 2000.

SHUKLA, D.D. \& WARD, C.W. Amino acid sequence homology of coat protein as a basis for identification and classification of the potyvirus group. Journal of General Virology 69:27032710. 1988.

SHUKLA, D.D., WARD, C.W. \& BRUNT, A.A. The potyviridae. Cambridge. University Press. CAB International. 1994.

STACE-SMITH, R. \& TREMAINE, J.H. Purification and composition of a potato virus Y. Phytopathology 60: 1785-1789. 1970.

THOMPSON, J.D., HIGGINS, D.G. \& GIBSON, T.J. Clustal W: Improving the sensitivity of progressive multiple sequence alignment through sequence weighting, position.specific gap penalties and weight matrix choice. Nucleic Acids Research 22:4673-4680. 1994. 